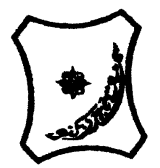

Bayero Journal of Pure and Applied Sciences, 11(1): 40 - 44

ISSN 2006 - 6996

\title{
AN ASSESSMENT OF THE PHYSICOCHEMICAL QUALITY OF SOME BOTTLE WATER SOLD IN KANO METROPOLIS, NIGERIA
}

\author{
${ }^{1}$ Iliyasu, H., ${ }^{2}$ Abdullahi, B.A. and ${ }^{3}$ Kawo, A.H. ${ }^{1}$ \\ Department of Science Education (Biology), Kano University of Science and Technology, Wudil, \\ Nigeria \\ ${ }^{2}$ Department of Biological Science, Bayero University, Kano, Nigeria \\ ${ }^{3}$ Department of Microbiology, Bayero University, Kano, Nigeria \\ "Correspondence author: hwiliyasu@gmail.com 08065579204
}

\begin{abstract}
Bottled water like any drinking water used for human consumption should be safe and of standard quality to ensure adequate public health significance. This study is aimed at assessing the physicochemical quality of some bottle water sold in Kano Metropolis. Studies on physicochemical parametric analysis were conducted. A total of 40 samples comprising of 4 different brands were randomly selected from different location. Physicochemical parameters of water samples such as Temperature, $\mathrm{pH}$, Electrical conductivity, Total dissolved solids, turbidity, Magnesium, Calcium, Lead, Copper, Zinc, Bicarbonate, Chloride, Nitrate and Phosphate were analyzed using standard methods of water analysis. The Results of physicochemical parameters were within the drinking water regulatory standard. However, zinc, lead and copper was found to exceed the bottle drinking water standard in the ranges of $3.91-6.17 \mathrm{Mg} / \mathrm{l}, 0.29-0.47 \mathrm{Mg} / \mathrm{l}$ and $1.54-2.67 \mathrm{Mg} / \mathrm{l}$ respectively; thereby rendering the water unfit to human consumption. There is the need to embark on routine monitoring and surveillances by the regulatory agencies involved to ensure effective implementation of WHO water safety plans from the catchment source to the consumer. This could be enhanced by replacing old pipes with new ones Bottled water industries should be designated away from heavy metal industries.
\end{abstract}

Keywords: Physicochemical, Bottled water quality, Kano metropolis

INTRODUCTION

The exponential trend of bottle water consumption over the last decades in Kano metropolis, Nigeria, cannot be over emphasized. However, more efforts are required to provide bottle water that meets the quality standards for human consumption. Safe drinking water as reported by WHO (2011) can save 1.8 million lives daily from incidence of water borne infection. Safe drinking water is an essential element for providing aesthetic and intellectual stimulation that lift the human spirit and improve health to human society Wegner et al. (2008). Thus, it is a powerful environmental determinant of health assurance as well as foundation for prevention and control of diseases as reported by (Kudesia and Ritu , 2003).

Literally bottled water can be defined as "any portable water that is treated of sanitary quality and intended for public consumption, bottled, distributed and offered for sale" (WHO, 2004 ; 2011). However, it can be simply referred to as water from some source (natural springs, wells, boreholes, municipal systems (Iliyasu et al., 2017) or other sources which are considered to be safe, of sanitary quality and fit for human consumption that a company has placed in plastic bottles, vessels, cans, laminated boxes; ranging from sizes of single serving to large carboys holding up to 80 liters resale for consumption (Magda et al., 2008).

It has been reported that, chemical qualities or composition of different type of bottled waters are largely influenced by geological and hydrological aspects of aquifers from which the water was drawn can result in the introduction of toxic and trace elements into the water in bottling process and treatment (Liee , 2011).It occurs in minute concentration in the order of $0.1 \mathrm{mg} / \mathrm{l}$ in natural waters ; however, levels beyond tolerance limit can be a threat and hazard to public ( Kudesia and Ritu 2003). Moreover, some contaminants in form of heavy metals can interfere with the development of reproductive, endocrine, immune and nervous system many of which interfere or mimic both male and female hormone, thus modifying development and reproduction (Kudesia and Ritu, 2003; WHO, 2004)

The quality of bottle water can substantially vary among brands as well as with time, different production runs depending on its source, treatment technology, manufacturing operations, personal hygiene practices and shelf life before use (Ajayi et al.,2008; Liee,2011; Iliyasu et al.,2017). 
It is against this background that, the paper is aimed at collecting some samples of bottle water sold within Kano metropolis, assessing its physicochemical quality and comparing the result with some national and international standard through survey design and laboratory experiment. This will be achieved with the following objectives:

1. To collect some samples of bottle water from different locations within Kano Metropolis

2. To assess some of the physicochemical qualities of the collected water samples and compare the result with some national and international standard.

Research Questions

1. How would the bottle water samples collected?

2. What are the physicochemical qualities and how would they be assessed?

\section{MATERIALS AND METHODS}

The research design involves survey design through physical examination of the bottled water samples (NAFDAC, 2004) and laboratory experiment. Forty bottle water samples comprising of ten each from four different brands were collected fortnightly around the metropolitan sample sites from retailed outlets.

Sample collection and Physicochemical Assessment of Water samples

Standard method of physicochemical analysis of water was used to collect; processed and analyzed the water samples using standard methods within 6 hours of collection. (WHO, 2004 ; APHA, 2005). This include: Temperature $\mathrm{pH}$, Electrical conductivity, Total dissolved solids, turbidity, Magnesium, Calcium, Lead, Copper, Zinc, Bicarbonate, Chloride, Nitrate and Phosphate.

\section{Determination of Temperature}

Temperature of water samples was determined according to the method described by (Udo et al.,2009; Njosi,2005).The temperature measurement probe was inserted in the water sample using probe number HI7662 of Hanna HI 255 model. The probe was allowed to stabilize and the reading was recorded in ${ }^{\circ} \mathrm{C}$ according to the manufacturers' instruction.

\section{Determination of $\mathrm{pH}$}

The $\mathrm{pH}$ of water samples was determined according to the method described by (Udo et al., 2009; Njosi, 2005) using $\mathrm{pH}$ meter probe number HI 7662 (HI255) model. pH meter was switched on and was allowed to stabilize; it was then calibrated using buffer of 4 and $7 \mathrm{pH}$ to ensure accurate reading after which the electrode of the meter was inserted into each of the sample and was allowed to stabilize for some seconds and the reading on the meter was recorded.

\section{Determination of Conductivity}

Electrical conductivity was determined according to the method described by (Udo et al., 2009) The meter was calibrated using standard potassium chloride solution after which the probe of the conductivity meter was suspended in air to Zero calibration. It was then immersed into the sample by taping the probe repeatedly to remove any trapped air bubble in the sleeve. The probe was allowed to stabilize and the reading on the meter was recorded according to the manufacturer's instruction in $\mu \mathrm{s} / \mathrm{cm}$.

Determination of Total Dissolved Solids (TDS) Total dissolved solid (TDS) was determined according to the method described by (Udo et al., 2009) with conductivity meter probe number HI 76310 (Hanna HI255) model. The meter was calibrated initially using standard potassium chloride solution and then the electrode of the meter was immersed in the sample. It was allowed to stabilize and the reading on the meter was recorded according to the manufacturer's instruction measured in milligram per liter $(\mathrm{mg} / \mathrm{l})$.

Determination of turbidity

Turbidity of water sample was determined according to the method described by Olajide (2012) with digital turbidity meter HACH $2100 \mathrm{~N}$ Model. The meter was switched on and was allowed to warm up for 10 minutes. $30 \mathrm{ml}$ of the sample was dispensed and transferred into the sample cell after which the turbidity of the sample was recorded.

\section{Determination of Nitrate}

Nitrate concentration was determined according to the method described by (Kudesia and Ritu, 2003;Njosi,2005; Udo et al., 2009; Olajide, 2012) using potable data logging spectrophotometer (DR/2010 HACH). The spectrophotometer was switched on and was adjusted to a wave length of $500 \mathrm{~nm}$ frequency. One sachet of nitrate reagent powder was transferred into a small bottle designed for the nitrate analysis and $25 \mathrm{ml}$ of the water sample was mixed with the reagent in the tube and was placed in the spectrophotometer. The meter was allowed to stabilize after which the reading was taken and multiplied by 4.427 according to the manual instruction.

Determination of phosphate

Phosphate concentration was determined as described by (Njosi, 2005; Udo et al., 2009; Olajide, 2012) using potable data logging Spectrophotometer (DR/2010 HACH) at a frequency wave length value of $890 \mathrm{~nm}$. 


\section{Special Conference Edition, November, 2018}

Twenty five milliliter $(25 \mathrm{ml})$ capacity bottle was filled up with the water sample and was mixed with the reagent powder and placed in the spectrophotometer according to the manual instruction and the reading was taken.

Determination of Lead, Calcium, Magnesium, and Copper and Zinc

Lead, calcium, magnesium, copper and zinc were determined according to the method of (AOAC, 1984; (Kudesia and Ritu, 2003; APHA, 2005; Njosi, 2005; Udo et al., 2009) .125ml of the water sample was distilled in a beaker and was digested by putting on a hot plate and evaporated at a temperature of $350^{\circ} \mathrm{C}$ to a concentration of $25 \mathrm{ml}$. The filter of the digest was allowed to cool. The digest was diluted up to $100 \mathrm{ml}$ volume with distilled water and was aspirated into an air acetylene flame of the Atomic Absorption Spectrophotometer Model 210VGP (AAS) The absorbance at auto zero set was read after the ready key display at an absorbance of $279.5 \mathrm{~nm}$ for each sample. For example Zinc absorbance was read at a current of 2.0 ohms lamp.

Determination of chloride

Chloride of water sample was determined according to the argentometric method described by (AOAC,1984; Njosi, 2005) $5 \mathrm{ml}$ to $20 \mathrm{ml}$ of the water sample was transferred into a conical flask and 2 to 3 drops of potassium chromate was added to obtain yellowish coloration. It was titrated with 0.1 molar silver nitrate solutions until the pink color end point was attained after which the record of the volume of titrate used was noted and recorded and the result was calculated.

\section{Determination of Bicarbonate}

Bicarbonate was determined according to the titrimetric method described by (AOAC, 1984; Njosi, 2005; Udo et al., 2009 ). 10ml of sample was introduced into a conical flask and 2 to 3 drops of phenolphthalein indicator was added. A color change in the water sample to a pink coloration indicated the presence of carbonate. The estimate of amount of carbonate was carried out by titration with $0 . \mathrm{IM}$ sulphuric acid to colorless neutralization point and the end point was noted and recorded. 2 drops of methyl orange indicator was added and titrated with same $0 . I M$ acid, until a color change from orange to pink was obtained, and the final reading was recorded.

\section{RESULTS AND DISCUSSION}

The values of $\mathrm{pH}$ ranged between; 6.6-7.0 which are within the recommended value by WHO/NAFDAC. The temperatures of all the four brands exceeded the aesthetic standard of palatability of $15^{\circ} \mathrm{C}$. Brand $\mathrm{C}$ had the highest electrical conductivity of $93.29 \mu \mathrm{S} / \mathrm{cm}$ and TDS of $43.81 \mathrm{mg} / \mathrm{l}$ while brand $A$ had the least electrical conductivity of $17.00 \mu \mathrm{S} / \mathrm{cm}$ with a TDS value of $7.96 \mathrm{mg} / \mathrm{l}$.

The values of all the brands were within the $1000 \mu \mathrm{S} / \mathrm{cm}$ standards recommended by WHO/NAFDAC. Brand $\mathrm{C}$ had the highest turbidity value of 0.55 NTU while the lowest turbidity of 0.14 NTU was recorded in brand D which showed a significance difference. However the result was within the standard limit by WHO/NAFDAC of 1 NTU. Brand D had the highest value of $105.9 \mathrm{mg} / \mathrm{l}$ of magnesium while brand $C$ had the least value of $66.15 \mathrm{mg} / \mathrm{l}$ and were within the recommended standards of $30-150 \mathrm{mg} / \mathrm{l}$. Brand $\mathrm{C}$ had the highest value of $175.98 \mathrm{mg} / \mathrm{l}$ of calcium, while brand $A$ had the lowest value of $124.40 \mathrm{mg} / \mathrm{l}$ and were within the recommended standard of $75-200 \mathrm{mg} / \mathrm{l}$. The highest chloride value of $28.4 \mathrm{mg} / \mathrm{l}$ was recorded in sample $B$ while the lowest value was recorded in brand $D$, all the brands met the recommended chloride concentration value of $250 \mathrm{mg} / \mathrm{l}$. Brand A had the highest bicarbonate value of $46.514 \mathrm{mg} / \mathrm{l}$ while brand $\mathrm{d}$ had the lowest value of $19.82 \mathrm{mg} / \mathrm{l}$. Brand $A$ had the highest nitrate value of $0.868 \mathrm{mg} / \mathrm{l}$ while the least value of $0.67 \mathrm{mg} / \mathrm{l}$ was recorded in brand $B$ and was within the regulatory standard limit of $50 \mathrm{mg} /$ liter. The highest value of $0.307 \mathrm{mg} / \mathrm{l}$ of phosphate was recorded in brand $A$ while brand $B$ had the least value of $0.254 \mathrm{mg} / \mathrm{l}$; the concentration of phosphate was within the regulatory standard limit of $5 \mathrm{mg} / \mathrm{l}$

The mean concentration of lead was found to be higher in all the brands than the zero (0) WHO/NAFDAC standard which by implication is toxic to consumers. The toxicity effect of lead poison symptoms over long term exposure according to (Nriagu,1988; Kudesia and Ritu,2003;Olajide,2012) include; mild anaemia through heamoglobin synthesis disruptions, brain damage, vomiting, loss of appetite, convulsion, uncoordinated body movements, metallic tastes, changes in bone marrow, trouble in urine system, blue line, dysfunctions of the gastrointestinal tract and headache. Onimawo, (2013) attributed crime and antisocial behaviors in children to high levels of lead beyond concentration in drinking water source. Olajide (2012) reported that, sources of Lead in drinking water may be from water pipes and faucet, paint pigments, car and generator exhausts from chemical industries, insecticides and ceramic glazes. Studies have demonstrated that, toxicity of lead as a result of underground water contamination as through land fill of Polyvinyl chloride (PVC) pipes leaches lead organic compounds additive materials of barium/zinc and cadmium/zinc used as 
stabilizers in PVC USEPA (1986) as well as high cost and time of replacing old solder pipe line with new ones might be the route of exposure to higher concentrations. The findings was in line with the findings of Al-Saleh (1996) in Riyadh Saudi Arabia also recorded higher level of lead in bottled water and Dabaka (2002) in Canada also recorded high level of lead because of standing time.

Copper was also found to be above the drinking water standards of 1.0 as compared to WHO/NAFDAC. Copper contaminants can get into water bodies over a long distance of $8 \mathrm{~km}$ as fertilizers, fungicides as well as algaecides as reported by Olajide (2012). Copper occurs in drinking water as native metal and in sulphur ores in nature and often increase during distribution, especially in systems with acidic $\mathrm{p}^{\mathrm{H}}$ or higher carbonates waters with alkaline $\mathrm{P}^{\mathrm{H}}$. Longer time exposure to concentrations above standard for example at concentration $\mathrm{Cu}$ (470mg) in the body is toxic and is characterized by symptoms of hypertension, kidney and liver damage sporadic fever, uremia, pathological changes in brain tissue, coma and finally death(Kudesia and Ritu,2003). The result of the researcher was in line with studies conducted by Al-Saleh (1996) in Riyadh Saudi Arabia that also recorded copper concentration in bottled water above WHO standard.
Zinc was also found to be above the $3 \mathrm{mg} / \mathrm{l}$ standard of WHO/NAFDAC .Zinc occurs in nature as sulphide, silicate and zincate $(\mathrm{ZnO})$. Studies had demonstrated a linear relationship between survival and concentration of zinc in soft waters. (WHO,2004) Infants and children symptoms include delay in physical and mental development thus; affecting the retention span and learning ability (Kudesia and Ritu, 2003) AlSaleh (1996) in Riyadh, Saudi Arabia also recorded exceeded WHO limit of Zinc, Saleh et al. (2001) in Egypt, Ikem et al. (2002) in Alabama also recorded high Zinc level above USEPA \& EU standard for drinking water. Muhammad et al. (2010) in India recorded a exceeded WHO limit in a similar study as it was recorded from the findings.

\section{CONCLUSION}

In conclusion, physicochemical qualities of the bottle water such as Temperature, $\mathrm{pH}$, Electrical conductivity, Total dissolved solids, Turbidity , Magnesium, Calcium, Bicarbonate, Chloride, Nitrate and Phosphate were within the drinking water standard.

However, lead, zinc and copper were found to exceed the WHO/NAFDAC standard and might render the bottled water unfit for human consumption as it can lead to health hazards over long exposure.

Table 1: Mean Variations of Physicochemical Parameters of Bottled Drinking Water Samples

\begin{tabular}{|c|c|c|c|c|c|c|c|c|}
\hline Parameters & Unit & A & B & C & D & $\begin{array}{l}\text { WHO/ } \\
\text { NAFDAC }\end{array}$ & $\begin{array}{l}\text { USEPA/ } \\
\text { USFDA }\end{array}$ & S.E \\
\hline Temperature & ${ }^{\circ} \mathrm{C}$ & $29.26^{a}$ & $29.52^{a}$ & $29.18^{\mathrm{a}}$ & $29.70^{\mathrm{a}}$ & 15 & $\mathrm{~N} / \mathrm{A}$ & 0.233 \\
\hline $\mathrm{P}^{\mathrm{H}}$ & $\begin{array}{l}\text { Scale } \\
\text { unit }\end{array}$ & $6.7^{\mathrm{a}}$ & $6.9^{\mathrm{a}}$ & $7.0^{\mathrm{a}}$ & $6.6^{\mathrm{a}}$ & $6.5-8.5$ & $6.5-8.5$ & 0.172 \\
\hline $\begin{array}{l}\text { Electrical } \\
\text { conductivity }\end{array}$ & $\begin{array}{l}\mu \mathrm{S} / \\
\mathrm{cm}\end{array}$ & $17.00^{\mathrm{b}}$ & $70.12^{\mathrm{a}}$ & $93.29^{\mathrm{a}}$ & $33.0^{\mathrm{D}}$ & 1000 & - & 8.171 \\
\hline $\begin{array}{l}\text { Total dissolved } \\
\text { solids }\end{array}$ & $\mathrm{Mg} / \mathrm{l}$ & $7.96^{\mathrm{b}}$. & $32.93^{\mathrm{a}}$ & $43.81^{a}$ & $15.50^{\mathrm{b}}$ & 500 & 500 & 3.838 \\
\hline Turbidity & NTU & $0.27^{\mathrm{b}}$ & $0.26^{\mathrm{b}}$ & $0.55^{\mathrm{a}}$ & $0.14^{\mathrm{b}}$ & $1-<5$ & N/A & 0.048 \\
\hline Magnesium & $\mathrm{Mg} / \mathrm{l}$ & $86.07^{\mathrm{a}}$ & $69.19^{\mathrm{a}}$ & $66.15^{\mathrm{a}}$ & $105.91^{\mathrm{a}}$ & $30-150$ & - & 14.190 \\
\hline Calcium & $\mathrm{Mg} / \mathrm{l}$ & $124.40^{\mathrm{a}}$ & $141.54^{\mathrm{a}}$ & $175.98^{\mathrm{a}}$ & $144.12^{\mathrm{a}}$ & $75-200$ & - & 18.146 \\
\hline Lead & $\mathrm{Mg} / \mathrm{l}$ & $0.29^{\mathrm{b}}$ & $0.450^{\mathrm{a}}$ & $0.427^{\mathrm{a}}$ & $0.472^{\mathrm{a}}$ & 0.01 & 0 & 0.037 \\
\hline Copper & $\mathrm{Mg} / \mathrm{l}$ & $1.553^{\mathrm{b}}$ & $2.524^{\mathrm{a}}$ & $2.679^{a}$ & $1.548^{\mathrm{b}}$ & 1.0 & 1.0 & 0.181 \\
\hline Zinc & $\mathrm{Mg} / \mathrm{l}$ & $3.911^{\mathrm{a}}$ & $5.689^{\mathrm{a}}$ & $3.911^{\mathrm{a}}$ & $6.177^{\mathrm{a}}$ & 3.0 & 5.0 & 0.470 \\
\hline Bicarbonate & $\mathrm{Mg} / \mathrm{l}$ & $46.514^{a}$ & $41.419^{a}$ & $21.354^{\mathrm{b}}$ & $19.824^{\mathrm{b}}$ & - & - & 4.700 \\
\hline Chloride & $\mathrm{Mg} / \mathrm{l}$ & $24.847^{a}$ & $28.400^{\mathrm{a}}$ & $26.625^{\mathrm{a}}$ & $17.750^{\mathrm{a}}$ & 250 & 250 & 3.272 \\
\hline Nitrate & $\mathrm{Mg} / \mathrm{l}$ & $0.868^{\mathrm{a}}$ & $0.679^{\mathrm{a}}$ & $0.785^{\mathrm{a}}$ & $0.808^{\mathrm{a}}$ & 50 & 10 & 0.046 \\
\hline Phosphate & $\mathrm{Mg} / \mathrm{l}$ & $0.307^{\mathrm{b}}$ & $0.254^{\mathrm{b}}$ & $0.663^{\mathrm{a}}$ & $0.796^{\mathrm{a}}$ & 5.0 & - & 0.026 \\
\hline
\end{tabular}

Student -Newman-Keuls Test $a=0.05$; Means values with the same letter are not significantly different

Key: $\mathrm{mg} / \mathrm{l}$ =milligram per liter; NTU= Naphlometric Turbidity unit; N/A = not available; S.E standard error 


\section{RECOMMENDATIONS}

The following recommendations are made from the findings

1. There is the need to embarked routine monitoring and surveillances by the regulatory agencies involved to ensure effective implementation of WHO water safety plans from the catchment source to the consumer.

\section{REFERENCES}

Ajayi, A.A, Sridhar, M., Adekunle, N. and Oluwande, P.A. (2008).Quality of bottled Water Sold in Ibadan Metropolis; Nigeria: African Journal of Biomedical Research, 11:251-258 ISSN 1119-5096.

Al-Saleh , I. A. (1996). Trace Elements in Drinking Water coolers collected from Primary School Riyadh, Saudi Arabia Sci. Total Environ March, 29: 181(3):218-21.

A.O.A.C.(1984). Association of Official Analytical Chemist, Official Methods of Water Analysis: 14th edition Washington D. C. USA.

APHA (2005) American Public Health: Eaton, A.D. Clesceri, L.S. Rice, E.W. and Greenberg, E.A (eds.): Standard Methods for Examination of Water and Waste Water 21st Edition Washington D.C 20001- 3710.

Dabaka, R.W. (2002). Survey of Trace Elements of Bottled Drinking Water Sold in Canada. Food Additives and Contaminants: .Aug:19(8): 21-32.

Ikem, A., Odueyungbo, S., Egiebor, N.O. and Nyavor, K.(2002)."Chemical Quality of Bottled Water sold from three Cities in Eastern Alabama" Sci. Total Environ. , 288:165-175

Iliyasu , H. Abdullahi , B.A. and Kawo , A.H. (2017) . An Assessment of the Microbiological Quality of some bottle water sold in Kano Metropolis Nigeria Bayero Journal of Pure and Applied Sciences, 10 (1):142-145

Kudesia, V.P and Ritu, J. (2003) . Water Pollution: (Principles of Disinfection of Drinking Water and its Analysis) 5th Edition. Published by K. T. Mittal for Pragati Prakashan; Printed at Rat Printers, Meerut: pp. 738.

Liee, Y. L. (2011). Is shell life of bottled water a cause for concern? Thesis in Masters in Technology: Faculty of Applied and Computer Science, Val University of Technology (VUT).

Magda, M.A., AbdulEl-Salam, Engy, M.A., ElGhitany, and Muhammad, M .M. Kassem,(2008). Quality of Water bottle brands in Egypt and Biological Water examination. Institute of Public Health: Alexandria University, Egypt.

Muhammad, M. A., Khan, R. U. and Habibah, L. (2010) . Study of Trace Elements in Ground Water of Western Uttar Pradesh, India; Scientific Research and Essay Vol.5 (20) Pp3175-3182: http://www.academic journals.org/SRE.

NAFDAC,(2004). Guide lines for Registration of Packaged Water in Nigeria. National Agency
2. Redoubling of campaign awareness to stakeholders to some extent can also reduce the level of exposure. This could be achieved with replacing old pipes with new ones.

3. Bottled water industries should be designated away from heavy metal industries

For Drug Administration Control: Decree no. 20 of 1999.

Njosi, J.A (2005). Water Quality Management Analysis and Analytical Techniques .Department of Industrial Safety \& Environmental Technology: Petroleum training Institute Effurum, Delta State, Nigeria.

Nriagu, J.O., (1988). A silent epidemic of environmental Metal Poisoning: Environmental Pollution, 50: 139-161.

Olajide, D.A. (2012). Study of Trace Elemental Quality in Drinking Water Supply in Ifelodun L.G.A. Osun State Nigeria. M.Sc. Thesis unpublished in Analytical Chemistry: Bayero University Kano, Nigeria.

Onimawo, I. A. (2013) . "Clean and Safe Water as an Important Part of Good Family Nutrition" Wellington Hotel, Warri Delta State: Nigeria. Nigerian Punch

Saleh, M. A., Gwane, E, Jones, J. Wilson, B.(2001). "Chemical Evaluation of Commercial Bottling Drinking Water Sold in Egypt .J. of food Composition and Analysis: 14,127-152

Udo , E. J, Trenchard, O.I, Joseph, A.O, Anthony O.A and Ivara , E.E. (2009). Manual of Soil, Plant And Water analysis, Published by Sibon Books Limited. Flat 15, Block 6, Fourth Avenue, Festac: Lagos State.

USEPA (1986) Key Sampling Parameters Fact Sheet, Ohio EPA; Michigan Water Standards Administrative Rule Part 4, P, A. 481, National Resource and Environmental Protection Agency: and from

http.//www.epa.gov/safewater/mcl.html.

Wagner, I. Marsalek, J. and Breil, P. (2008). Aquatic Habitat in Sustainable Urban Water Management Science Policy and Practice: Urban Water Series Vol.4, Published Jointly by UNESCO, Taylor and Francis Group 7 Place de Fonteny 75007 Pans France: pp. 32-46.

WHO, (2004).Guide lines for Drinking Water Quality, 3rd Edition, Geneva; Available at http://www.who.int/water-sanitationhealth/dwq/en: (Last accessed January, 2007).

WHO, (2011). Guide lines for Drinking Water Quality, fourth Edition; Geneva: Available online http: / / wholipdoc. who.int/publication/2011 19789241548151-eng.pdf.Assessed:(Last assessed on 25th March, 2012). 